\title{
Effect of Angiotensin II on Ammonia Production and Secretion by Mouse Proximal Tubules Perfused In Vitro
}

Glenn T. Nagami

With the technical assistance of Evelyn M. Warech

Medical and Research Services, Veterans Affairs Medical Center West Los Angeles, Los Angeles 90073; and Department of Medicine, University of California at Los Angeles School of Medicine, Los Angeles, California 90024

\begin{abstract}
The effects of angiotensin II on total ammonia $\left(\mathrm{tNH}_{3}\right)$ production and net secretion were investigated using in vitro microperfused mouse $S_{2}$ proximal tubule segments incubated in KrebsRinger bicarbonate buffer containing $0.5 \mathrm{mM}$ L-glutamine. Basolateral exposure of mouse $S_{2}$ segments to $10^{-11}, 10^{-10}$, and $10^{-9} \mathrm{M}$ angiotensin II stimulated $\mathrm{NNH}_{3}$ production rates by 23 , 52, and 49\%, respectively. Addition of $10^{-6} \mathrm{M}$ angiotensin II inhibited the $\mathrm{tNH}_{3}$ production rate by $34 \% \cdot 10^{-10} \mathrm{M}$ angiotensin II inhibited net luminal secretion of $\mathrm{tNH}_{3}$ in the presence of enhanced luminal acidification and in the absence of altered luminal $\mathrm{TNH}_{3}$ efflux rates. Measurements of intracellular $\mathrm{pH}$ $\left(\mathrm{pH}_{\mathrm{i}}\right)$ and intracellular calcium concentration $\left(\mathrm{CCa}^{2+} \mathrm{l}_{\mathrm{i}}\right)$ suggested that the effects of angiotensin II on $\mathrm{tNH}_{3}$ production were not mediated by changes in $\mathrm{pH}_{\mathrm{i}}$ but by the stimulatory effect of angiotensin II correlated with increased $\left[\mathrm{Ca}^{2+}\right]_{\text {. }}$. Inhibition of the calcium-calmodulin-dependent pathway with W-7 blocked the stimulatory effect of $10^{-10} \mathrm{M}$ angiotensin II on $\mathrm{tNH}_{3}$ production and luminal acidification. These results indicate that angiotensin II has concentration-dependent effects on $\mathrm{tNH}_{3}$ production; that its action to stimulate $\mathrm{tNH}_{3}$ production may be mediated by rises in $\left[\mathrm{Ca}^{2+}\right]_{i}$ and the calcium-calmodulin pathway; and that angiotensin II, at concentrations that stimulate $\mathrm{tNH}_{3}$ production, inhibits net luminal ammonia secretion by a mechanism that is not mediated by diminished luminal acidification or by changes in luminal ammonia efflux rates. $(J$. Clin. Invest. 1992. 89:925-931.) Key words: ammoniagenesis • ammonia transport • intracellular calcium • intracellular pH
\end{abstract}

\section{Introduction}

Angiotensin II is a potent regulator of proximal tubule functions, including fluid and bicarbonate transport (1-4). Because total ammonia ( $\left.\mathrm{tNH}_{3}=\mathrm{NH}_{3}+\mathrm{NH}_{4}^{+}\right)^{1}$ production and transport are also important functions of the proximal tubule in that they account for the major portion of $\mathrm{tNH}_{3}$ that appears in the final urine (5-9), the effects of angiotensin II on $\mathrm{tNH}_{3}$ produc-

Address correspondence to Glenn T. Nagami, M. D., Building 114, Room 317, Veterans Affairs Medical Center West Los Angeles, Wilshire and Sawtelle Boulevards, Los Angeles, CA 90073. 1991.

Received for publication 4 June 1991 and in revised form 22 October

1. Abbreviations used in this paper: BCECF-AM, 2-biscarboxyethyl5,6-carboxyfluorescein acetoxymethyl ester; $\left[\mathrm{Ca}^{2+}\right]_{i}$, intracellular calcium concentration; $\mathrm{tNH}_{3}$, total ammonia.

The Journal of Clinical Investigation, Inc.

Volume 89, March 1992, 925-931 tion and transport by the proximal tubule should be explored. Recent studies by Chobanian and Julin (10) have demonstrated a stimulatory effect of $10^{-8} \mathrm{M}$ angiotensin II on $\mathrm{tNH}_{3}$ production by isolated dog proximal tubule fragments. The effects of angiotensin II on $\mathrm{tNH}_{3}$ transport in the proximal tubule are not known.

In previous studies, we have used the isolated perfused mouse proximal tubule segment to examine the effects of acute changes in luminal flow rates, $\mathrm{pH}$, and potassium concentration in vitro on ammonia production and transport (11-13). The main advantages of the isolated perfused tubule model are that the origin of the examined segment is known; that the tubule lumen is perfused, so that $\mathrm{tNH}_{3}$ production and luminal secretory rates may be measured; and that during the isolation procedure no proteolytic enzymes are used that could alter the expression of receptor or transporter functions.

The purpose of the present study was to determine the effect of angiotensin II on $\mathrm{tNH}_{3}$ production and secretion by proximal tubules perfused in vitro. In the present studies, we examined the effects of angiotensin II on $\mathrm{tNH}_{3}$ production and secretion by isolated perfused mouse proximal tubule segments. The results of this study demonstrate that angiotensin II has concentration-dependent effects on $\mathrm{tNH}_{3}$ production by the mouse proximal tubule. By contrast, at a concentration that stimulates $\mathrm{tNH}_{3}$ production rates, angiotensin II inhibits net $\mathrm{tNH}_{3}$ secretion by the proximal tubule, despite stimulation of amiloride-sensitive luminal fluid acidification, suggesting a dissociation between luminal $\mathrm{tNH}_{3}$ secretion and $\mathrm{Na}^{+}-\mathrm{H}^{+}$exchanger activity.

\section{Methods}

Isolation and perfusion of mouse proximal tubules. The isolation and perfusion of mouse proximal tubule segments has been previously described in detail $(11,12,14)$. As in previous studies, male Swiss Webster mice weighing 25-35 g were maintained on a standard Purina Rodent Chow (Ralston Purina, St. Louis, MO) diet and were given water ad lib. Proximal tubule segments were dissected from the renal cortex under microscopic guidance using needle-tipped forceps. The mid-portion of the proximal tubule (" $\mathrm{S}_{2}$ ") consisted of the late convoluted and early straight portions. The mean length of $S_{2}$ segments was $0.8 \pm 0.1 \mathrm{~mm}$, and ranged from 0.6 to $1.0 \mathrm{~mm}$. A dissected segment was placed in a modified microperfusion chamber in which the volume was reduced to $\sim 200 \mu \mathrm{l}$. In experiments in which ammonia production rates were to be made, one end of the segment was cannulated and perfused with Krebs-Ringer bicarbonate (KRB) buffer (see Solutions below), and the distal end of the segment remained open to the bath medium. The tubule was washed by exchanging the bath solution several times with the buffer to be used in the incubation. The standard buffer used in the bath solution was $\mathrm{KRB}$ buffer containing $0.5 \mathrm{mM} \mathrm{L-glutamine,} \mathrm{pH} 7.4$, preequilibrated with $95 \% \mathrm{O}_{2}: 5 \% \mathrm{CO}_{2}$ at $37^{\circ} \mathrm{C}$. The volume of the incubation buffer was reduced to $\sim 150-200 \mu \mathrm{l}$ and the bath medium and perfused tubule were covered with mineral oil pregassed with $95 \%$ 
$\mathrm{O}_{2}: 5 \% \mathrm{CO}_{2}$. The tubule was incubated for $20-30 \mathrm{~min}$ at $37^{\circ} \mathrm{C}$. During the incubation period, the mineral oil directly above the tubule was bubbled with a gas jet of $95 \% \mathrm{O}_{2}: 5 \% \mathrm{CO}_{2}$, which served to mix the incubation medium. At the end of the incubation period, an aliquot of the bath medium was taken and assayed for $\mathrm{tNH}_{3}$, as described by us previously $(11,14)$, using enzymatic reactions coupled to the bacterial luciferase bioluminescence reaction. The volume of the incubation medium was determined from the dilution of added amounts of trypan blue dye.

In studies examining net $\mathrm{tNH}_{3}$ secretion, the fluid leaving the distal end of the perfused segment was collected under mineral oil as timed fluid samples. The rate at which $\mathrm{tNH}_{3}$ left the distal end of the perfused segment represented the net luminal secretion of $\mathrm{tNH}_{3}$.

Total ammonia assay. The ultramicroassay used to determine the concentration of $\mathrm{tNH}_{3}$ in the incubation bath was based on a series of enzymatic reactions coupled to the bacterial luciferase bioluminescence reaction (11). The $\mathrm{tNH}_{3}$ present in the sample or standard reacts with 2-oxoglutarate and NADH to form glutamate and NAD ${ }^{+}$. The $\mathrm{NAD}^{+}$thus formed was equal to the amount of $\mathrm{tNH}_{3}$ present in the original sample and was measured using a modification of the bacterial luciferase method of Brolin et al. (15). The rate of light emission was measured using a photometer (model 20; Turner Designs, Mountain View, CA). The steady-state light emission rate was proportional to the amount of $\mathrm{tNH}_{3}$ present in the sample.

The $\mathrm{tNH}_{3}$ production rate (pmol/min per $\mathrm{mm}$ ) is bath volume $(\mu \mathrm{l})$ $\times \mathrm{tNH}_{3}$ concentration $(\mu \mathrm{M})$ /incubation time $(\mathrm{min}) \times$ tubule length $(\mathrm{mm})$.

Net luminal secretion of $\mathrm{tNH}_{3}$ was calculated from the rate at which $\mathrm{tNH}_{3}$ left the distal end of the perfused segment in timed luminal fluid collections, so that net $\mathrm{tNH}_{3}$ secretion (pmol/min per $\mathrm{mm}$ ) is total content $(\mathrm{pmol}) /$ collection time $(\mathrm{min}) \times$ tubule length $(\mathrm{mm})$.

Measurement of intraluminal $\mathrm{pH}$. The $\mathrm{pH}$ of the fluid leaving the distal end of the perfused segment was measured using a pH-sensitive liquid ion exchanger microelectrode as described by us before (14). In these studies, the microelectrode was introduced into the collection pipette so that the tip was placed adjacent to the distal end of the perfused segment. The tip of the electrode was designed to be thin enough to be held next to the luminal opening without impeding flow. The electrode was connected via a silver-silver chloride wire to a high input impedance electrometer (Duo 773; World Precision Instruments, Sarasota, FL).

Measurement of intracellular $\mathrm{pH}\left(\mathrm{pH}_{\mathrm{i}}\right)$. Changes in $\mathrm{pH}_{\mathrm{i}}$ were monitored in perfused mouse $\mathrm{S}_{2}$ segments using the cell permeant, $\mathrm{pH}$-sensitive fluorescent probe 2-biscarboxyethyl-5,6-carboxyfluorescein acetoxymethyl ester (BCECF-AM). The dissected tubule segment was held, cannulated, and microperfused using concentric pipettes and was bathed in a modified, temperature-controlled perfusion chamber with an inlet port that permitted constant perfusion of the tubule and an exit drain port. The perfusion of the bath solution and perfusion of the lumen ensured the removal of any dye that may have leaked into the extracellular compartments. The fluid entering the chamber could be changed rapidly by switching the source of fluid from one reservoir to another. The reservoir and glass tubing leading to the chamber were water-jacketed to maintain a constant temperature so that the fluid entering the chamber was $37^{\circ} \mathrm{C}$. The solutions in the reservoirs were gassed with $95 \% \mathrm{O}_{2}: 5 \% \mathrm{CO}_{2}$. A minimum amount of plastic tubing was used to connect sections of glass tubing to avoid excessive loss of gas. The $\mathrm{pH}$ of the fluid entering the chamber was 7.44 $\pm 0.01(n=20)$ and was monitored continuously using a small $\mathrm{pH}$ probe (Lazar Research Laboratories, Los Angeles, CA).

After background fluorescent measurements were taken, the proximal tubule segment was loaded with $1 \mu \mathrm{M}$ BCECF-AM for $20 \mathrm{~min}$. After the excess dye was washed away, the fluorescence emission at 535 $\mathrm{nm}$ was measured in response to alternating excitation wavelengths of 440 and $495 \mathrm{~nm}$ using the UMANS data acquisition and analysis system (Chester Regen, Urbana, IL). The microfluorometer consisted of an inverted epifluorescent microscope (Diaphot; Nikon Inc., Melville, NY) equipped with a photon counter and with an impeller driven by a computer-controlled stepper motor for alternating filters in front of the xenon lamp light source.

$\mathrm{pH}_{\mathrm{i}}$ was calculated by comparing ratios of emission fluorescence intensities at $535 \mathrm{~nm}$ obtained at excitation wavelengths of 495 and 440 $\mathrm{nm}$ with ratios obtained in the same tubule using the nigericin-high potassium $\mathrm{pH}$ clamping technique of Thomas et al. (16). In preliminary studies, ammonium chloride loading led to acute alkalinization of $\mathrm{pH}_{\mathrm{i}}$ and removal led to acute acidification in a way consistent with results obtained by others in the proximal tubule (17).

Measurement of intracellular calcium concentration $\left(\left[\mathrm{Ca}^{2+}\right]_{i}\right)$. Changes in $\left[\mathrm{Ca}^{2+}\right]_{\mathrm{i}}$ were followed using the calcium-sensitive, cell-permeant fluorescent dye, fura 2-AM (18). The tubule segments were perfused in the same way as that described above for the measurement of $\mathrm{pH}_{\mathrm{i}}$. The cells of the perfused segment were loaded with 2-5 $\mu \mathrm{M}$ fura 2-AM for $30 \mathrm{~min}$ after an initial check of the background fluorescence of the tubule. With this system, ratios of emission intensities minus background at $510 \mathrm{~nm}$ in response to excitation at 340 and $380 \mathrm{~nm}$ could be made at 0.5 -s intervals. Because of photobleaching of the dye, prolonged continuous observation of $\left[\mathrm{Ca}^{2+}\right]_{i}$ was not possible so that intermittent fluorescence measurements were obtained to determine calcium measurements over a 20 -min period. With these precautions, emission fluorescence fell by $<10 \%$ and the ratios of emission intensities remained stable in this flow-through system in the absence of changes in the extracellular environment.

$\left[\mathrm{Ca}^{2+}\right]_{i}$ was calculated from the ratio of fluorescent emission intensities minus background at 340 and $380 \mathrm{~nm}$ excitation wavelength $(R)$, from the maximum ratio of fluorescent emission intensities $\left(R_{\max }\right)$, and from the minimum ratio of fluorescent emission intensities $\left(R_{\min }\right)$ using the formula of Grynkiewicz et al. (18):

$$
\left[\mathrm{Ca}^{2+}\right]=K \mathrm{~d} \times \frac{\left(R-R_{\min }\right)}{\left(R_{\max }-R\right)} \times(S f / S b),
$$

where $K_{\mathrm{d}}$ applies to the binding of calcium to fura $2(220 \mathrm{nM}), S_{\mathrm{b}}$ is the fluorescence of the calcium-bound dye, and $S_{\mathrm{f}}$ is the fluorescence of the calcium-free dye at $380 \mathrm{~nm}$ excitation light. $R_{\max }$ was obtained in the presence of $5 \mu \mathrm{M}$ ionomycin and $1 \mathrm{mM}$ extracellular calcium, whereas $R_{\min }$ was obtained in the presence of $5 \mu \mathrm{M}$ ionomycin, $0 \mathrm{mM}$ extracellular calcium, and $5 \mathrm{mM}$ EGTA. In preliminary studies, addition of 0.2 or $1 \mu \mathrm{M}$ ionomycin in the presence of extracellular calcium caused a marked rise in intracellular calcium.

Solutions. KRB buffer contained the following electrolytes (in $\mathrm{mM}): 140 \mathrm{NaCl}, 25 \mathrm{NaHCO}_{3}, 5 \mathrm{KCl}, 1 \mathrm{MgCl}, 1 \mathrm{NaH}_{2} \mathrm{PO}_{4}$, and $1 \mathrm{CaCl}$. Angiotensin II and [ $\left.\mathrm{Sar}^{1}, \mathrm{Val}^{5}, \mathrm{Ala}^{8}\right]$-angiotensin II (saralasin; Sigma Chemical Co., St. Louis, MO) were added in concentrations specified in the results. BCECF-AM, fura 2-AM, and W-7 (Molecular Probes, Eugene, OR) were prepared in 10,000X stock solutions of DMSO and added to achieve the final concentrations specified in results.

Statistical analysis. All data are presented as means \pm SE. Comparisons between two groups were made using Student's $t$ test and comparisons of means among greater than two groups were made using analysis of variance with multiple comparisons (method of Scheffe) (19).

\section{Results}

The rates of $\mathrm{tNH}_{3}$ production and net luminal secretion of $\mathrm{tNH}_{3}$ were stable for $\geq 45 \mathrm{~min}$ at $37^{\circ} \mathrm{C}$ under the conditions studied. All samples used in this study were obtained within 45 min of initiating the incubation period. All tubules excluded trypan blue, introduced at the conclusion of the incubation period.

Effects of angiotensin II on $\mathrm{NHH}_{3}$ production rates in $\mathrm{S}_{2}$ proximal tubule segments. $\mathrm{tNH}_{3}$ production rates were measured in $\mathrm{S}_{2}$ segments of the mouse proximal tubule $(n=5$ in each group) in the presence of various concentrations of angiotensin II in the basolateral bath solution (Fig. 1). The mean luminal perfusion flow rate was $20.8 \pm 0.9 \mathrm{nl} / \mathrm{min}$, with no sig- 


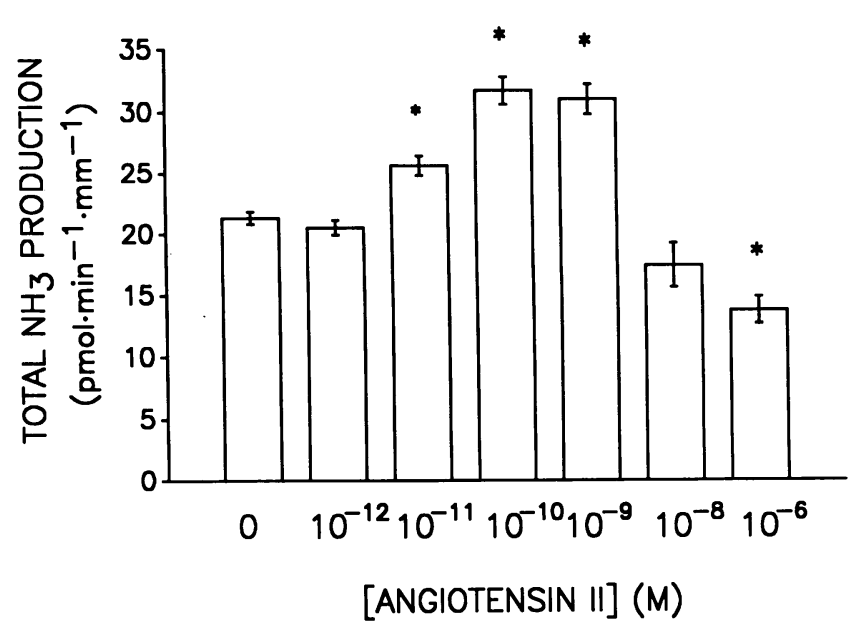

Figure 1. Angiotensin II stimulates the $\mathrm{tNH}_{3}$ production rate at $10^{-11}-10^{-9} \mathrm{M}$ but inhibits it at $10^{-6} \mathrm{M}$. ${ }^{*} P<0.05$ vs. $0 \mathrm{M}$ angiotensin II.

nificant differences among the groups studied. The rate of $\mathrm{tNH}_{3}$ production was significantly higher $(P<0.05)$ in the groups exposed to $10^{-11}, 10^{-10}$, and $10^{-9} \mathrm{M}$ angiotensin II $(25.6 \pm 0.8,31.7 \pm 1.1$, and $31.0 \pm 1.2 \mathrm{pmol} / \mathrm{min}$ per $\mathrm{mm}$, respectively) than in tubules exposed to 0 or $10^{-12} \mathrm{M}$ angiotensin II. Exposure to $10^{-8} \mathrm{M}$ angiotensin II had no significant effect on the rate of $\mathrm{tNH}_{3}$ production $(17.4 \pm 1.8 \mathrm{pmol} / \mathrm{min}$ per $\mathrm{mm})$. At a higher concentration of $10^{-6} \mathrm{M}$, the rate was significantly lower than control rates $(13.7 \pm 1.1, P<0.05)$. Thus, angiotensin II had a biphasic effect on $\mathrm{tNH}_{3}$ production by the mouse $\mathrm{S}_{2}$ segment such that $\mathrm{tNH}_{3}$ production rates were higher in $\mathrm{S}_{2}$ segments exposed to $10^{-11}-10^{-9} \mathrm{M}$ angiotensin II but were lower in segments exposed to $10^{-6} \mathrm{M}$ angiotensin II.

Effect of saralasin on $\mathrm{tNH}_{3}$ production. Saralasin, a direct angiotensin II antagonist, was added at $10^{-7} \mathrm{M}$ to the bath solution surrounding the perfused proximal tubule segments in the presence or absence of $10^{-10} \mathrm{M}$ angiotensin II. As shown in Fig. 2, the $\mathrm{tNH}_{3}$ production rates with the addition of saralasin by itself or with angiotensin II did not significantly differ from control rates (20.8 \pm 0.5 for saralasin + angiotensin II group; $n$ $=5$ in each group). Thus, saralasin blocked the effect of $10^{-10}$ $\mathrm{M}$ angiotensin II to stimulate the $\mathrm{tNH}_{3}$ production rate by

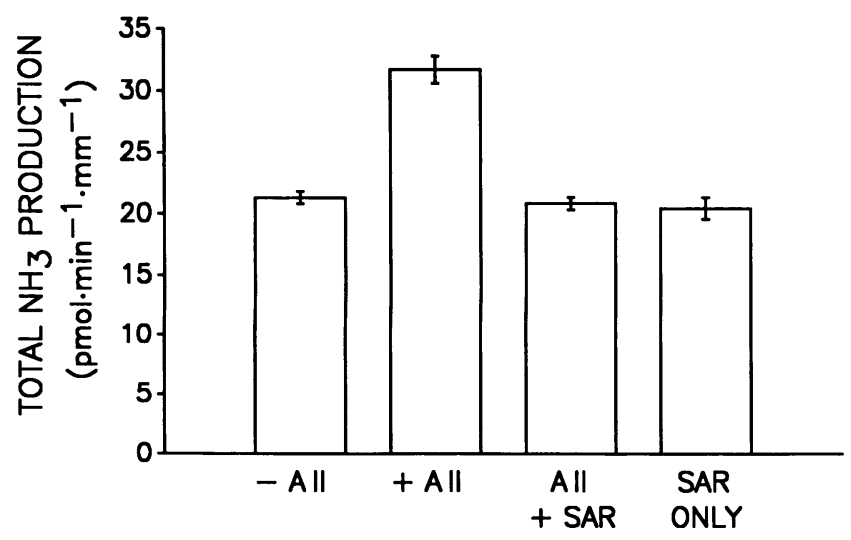

Figure 2. $10^{-7} \mathrm{M}$ saralasin (SAR) inhibits the stimulatory effect of $10^{-10} \mathrm{M}$ angiotensin II $(A I I)$ on the $\mathrm{tNH}_{3}$ production rate in mouse $\mathrm{S}_{2}$ segments. mouse proximal tubules without exerting a significant effect on $\mathrm{tNH}_{3}$ production rates by itself.

Effect of angiotensin II on net $\mathrm{tNH}_{3}$ secretion and luminal fluid acidification. The effect of the addition of $10^{-10} \mathrm{M}$ angiotensin II to the bath solution on net $\mathrm{tNH}_{3}$ secretion was examined (Fig. 3). The net luminal $\mathrm{tNH}_{3}$ secretory rate was significantly $(P<0.05)$ lower in tubules bathed in KRB buffer containing angiotensin II $(7.9 \pm 0.4 \mathrm{pmol} / \mathrm{min}$ per $\mathrm{mm})$ than in tubules bathed without angiotensin II (11.0 \pm 0.7$)$. Thus, at a concentration of angiotensin II that stimulated the $\mathrm{tNH}_{3}$ production rate, angiotensin II inhibited net $\mathrm{tNH}_{3}$ secretion such that the percentage of the $\mathrm{tNH}_{3}$ produced that was secreted into the lumen was reduced from $55 \%$ in control proximal tubule segments to $30 \%$ in angiotensin II-treated segments.

$\mathrm{Na}^{+}-\mathrm{H}^{+}$exchanger activity in the proximal tubule is stimulated by angiotensin II (20). Stimulation of the $\mathrm{Na}^{+}-\mathrm{H}^{+}$exchange would be expected to enhance net $\mathrm{tNH}_{3}$ secretion by increasing the luminal fluid acidity and by increasing $\mathrm{Na}^{+}$$\mathrm{NH}_{4}^{+}$exchange (14). To ascertain whether luminal acidification was stimulated by angiotensin II in isolated perfused mouse proximal tubule segments, angiotensin II $\left(10^{-10} \mathrm{M}\right)$ was added to the peritubular bath solution and luminal $\mathrm{pH}$ was monitored using a pH-sensitive microelectrode placed at the opening of the distal end of the perfused segment. The luminal fluid $\mathrm{pH}$ fell significantly in response to angiotensin II in a reversible fashion (Fig. 4). Addition of $1 \mathrm{mM}$ amiloride to the luminal perfusion solution completely blocked luminal acidification in the presence of peritubular angiotensin II ( $n=5$ in each group; luminal fluid $\mathrm{pH}=7.44 \pm 0.01$ in angiotensin II + amiloride vs. $7.29 \pm 0.01$ in angiotensin II alone; $P<0.01$ ). Thus, angiotensin II enhanced amiloride-sensitive luminal fluid acidification in mouse proximal tubule segments.

One possible mechanism by which angiotensin II could reduce net luminal $\mathrm{tNH}_{3}$ secretion despite enhanced $\mathrm{Na}^{+}-\mathrm{H}^{+}$exchanger activity would be through an increase in backflux of $\mathrm{tNH}_{3}$ out of the lumen. To examine whether angiotensin II affected luminal efflux of $\mathrm{tNH}_{3}$, we added known amounts of $\mathrm{tNH}_{3}(10 \mathrm{mM})$ to the luminal perfusion solution and determined the rate of efflux of $\mathrm{tNH}_{3}$ out of the lumen by measuring the $\mathrm{tNH}_{3}$ leaving the distal end of the perfused segment. As illustrated in Table I, there was no significant difference between the rate of efflux of $\mathrm{tNH}_{3}$ in tubules bathed in control $\mathrm{KRB}$ buffer without angiotensin II and tubules bathed in KRB

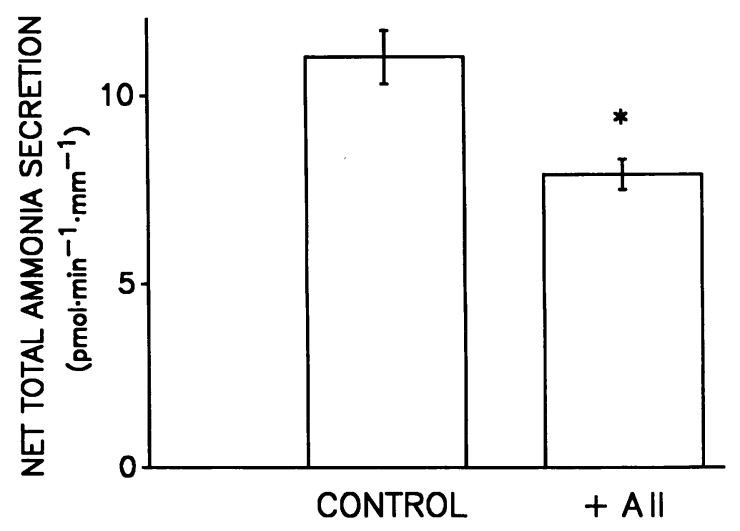

Figure 3. Angiotensin II $(A I I)$ at $10^{-10} \mathrm{M}$ inhibited net $\mathrm{tNH}_{3}$ secretion. ${ }^{*} P<0.05$ vs. control $(0 \mathrm{M}$ angiotensin II). 


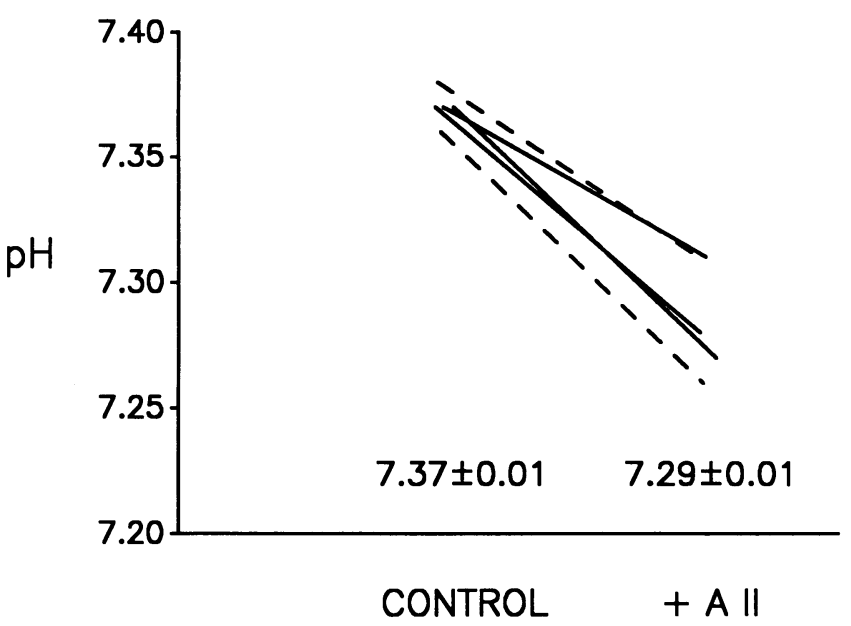

Figure 4. Angiotensin II $(A I I)$ at $10^{-10} \mathrm{M}$ significantly stimulated luminal fluid acidification. Dashed lines represent experiments in which luminal $\mathrm{pH}$ was measured in $\mathrm{S}_{2}$ segments exposed to A II and then A II was removed, whereas the solid lines represent segments initially exposed to no A II and then A II was added. ${ }^{*} P<0.01$ A II vs. control.

buffer containing $10^{-10} \mathrm{M}$ angiotensin II. Thus, angiotensin II had no measurable effect on $\mathrm{tNH}_{3}$ efflux out of the lumen.

Mediation of the stimulatory effect of angiotensin II on ammonia production and luminal acidification. $\mathrm{pH}_{\mathrm{i}}$ may mediate the stimulatory effect of systemic acidosis on $\mathrm{tNH}_{3}$ production and luminal acidification. Angiotensin II could stimulate both processes by primarily reducing the $\mathrm{pH}_{\mathrm{i}}$. As shown in Fig. 5 , $10^{-10} \mathrm{M}$ angiotensin II, which stimulated luminal acidification, had no net effect on $\mathrm{pH}_{\mathrm{i}}$ (control $7.01 \pm 0.02$ vs. angiotensin II $7.03 \pm 0.03 ; n=8$ in each group). Similarly, $10^{-6} \mathrm{M}$ angiotensin II, which inhibited $\mathrm{tNH}_{3}$ production rates, also had no significant effect on $\mathrm{pH}_{\mathrm{i}}$ (control $7.02 \pm 0.03$ vs. angiotensin II $7.02 \pm 0.02 ; n=7$ in each group). Thus, no measurable changes in $\mathrm{pH}_{\mathrm{i}}$ were involved in mediating the effects of angiotensin II on $\mathrm{tNH}_{3}$ production and luminal acidification. Furthermore, since luminal acidification involves $\mathrm{H}^{+}$exit from the cell to luminal fluid, the results suggest that exposure to $10^{-10} \mathrm{M}$ angiotensin II stimulates acid secretion and base removal at equal rates. These results suggest that, when stimulated by angiotensin II, luminal acidification (cellular acid extrusion) was balanced by equal rates of base removal or acid entry, leading to stable $\mathrm{pH}_{\mathrm{i}}$ measurements.

Chobanian and Julin (10) recently demonstrated that inhibitors of calcium-calmodulin-dependent pathway (W-7, trifluoperazine) inhibit the stimulatory effect of angiotensin II on $\mathrm{tNH}_{3}$ production in isolated dog proximal tubule segments.

Table I. Total Ammonia Efflux

\begin{tabular}{cccc}
\hline $\begin{array}{c}\text { Angiotensin II } \\
\text { concentration }\end{array}$ & $\begin{array}{c}\text { Tubule } \\
\text { length }\end{array}$ & Flow rate & $\begin{array}{c}\mathrm{tNH}_{3} \\
\text { efflux rate }\end{array}$ \\
\hline$M$ & $m m$ & $n l / m i n$ & pmol/min per mm \\
0 & $0.6 \pm 0.1$ & $20.9 \pm 0.9$ & $220 \pm 7$ \\
$10^{-10}$ & $0.6 \pm 0.1$ & $21.4 \pm 1.0$ & $230 \pm 6$
\end{tabular}

$n=6$ in each group. No statistically significant differences between groups.

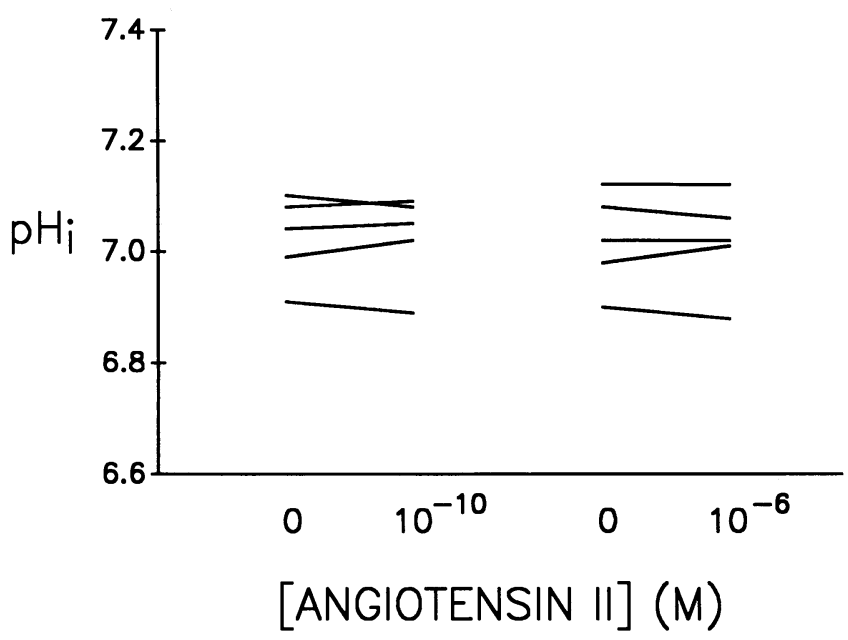

Figure 5. Absence of an effect of addition of $10^{-10}$ or $10^{-6} \mathrm{M}$ angiotensin II on intracellular $\mathrm{pH}$.

We examined the effect of addition of bath (basolateral) $10 \mu \mathrm{M}$ $\mathrm{W}-7$ on the effects of $10^{-10} \mathrm{M}$ angiotensin II on luminal acidification and $\mathrm{tNH}_{3}$ production rates. Although $\mathrm{W}-7$ by itself had no significant effect on luminal acidification $(\mathrm{pH} 7.37 \pm 0.01$ with and $7.36 \pm 0.01$ without $\mathrm{W}-7, n=5$ ), it blocked the stimulatory effect of angiotensin II on luminal acidification such that luminal $\mathrm{pH}$ increased from $7.28 \pm 0.01$ for angiotensin II to $7.39 \pm 0.01$ for angiotensin II $+\mathrm{W}-7(n=5)$. In addition, $\mathrm{W}-7$ inhibited the stimulatory effect of $10^{-10} \mathrm{M}$ angiotensin II on $\mathrm{tNH}_{3}$ production rate (Table II). Thus, both the effects of $10^{-10}$ $\mathrm{M}$ angiotensin II to stimulate $\mathrm{tNH}_{3}$ production and luminal acidification may be mediated through a calcium-calmodulindependent mechanism.

To explore further the role of $\left[\mathrm{Ca}^{2+}\right]_{\mathrm{i}}$ as a mediator of the actions of angiotensin $\mathrm{II},\left[\mathrm{Ca}^{2+}\right]_{\mathrm{i}}$ was determined in response to different concentrations of angiotensin II (Fig. 6). Control $\left[\mathrm{Ca}^{2+}\right]_{\mathrm{i}}$ without angiotensin $\mathrm{II}(n=5)$ was $100 \pm 5 \mathrm{nM}$. Exposure of cells to angiotensin II at $10^{-10} \mathrm{M}$ resulted in a significant sustained increase in $\left[\mathrm{Ca}^{2+}\right]_{\mathrm{i}}$, to $165 \pm 5 \mathrm{mM}$, whereas $10^{-6} \mathrm{M}$ angiotensin II had no significant effect on $\left[\mathrm{Ca}^{2+}\right]_{i}(103 \pm 7 \mathrm{nM})$. Such results are consistent with a role of an increased $\left[\mathrm{Ca}^{2+}\right]_{i}$ in the stimulation of $\mathrm{tNH}_{3}$ production in the mouse $\mathrm{S}_{2}$ segment since the concentrations of angiotensin II that increased $\left[\mathrm{Ca}^{2+}\right]_{i}$ are the same as those that increased $\mathrm{tNH}_{3}$ production rates (Fig. 1). On the other hand, the inhibitory effect of $10^{-6} \mathrm{M}$ angiotensin II on $\mathrm{tNH}_{3}$ production occurred in the absence of changes in $\left[\mathrm{Ca}^{2+}\right]$.

The effect of $10^{-10} \mathrm{M}$ angiotensin II on $\mathrm{tNH}_{3}$ production was also examined with the removal of extracellular calcium in

Table II. Effects of Angiotensin II and $\mathrm{W}-7$ on $\mathrm{tNH}_{3}$ Production

\begin{tabular}{lc}
\hline \multicolumn{1}{c}{ Conditions } & $\mathrm{tNH}_{3}$ production rates \\
\hline & pmol/min per $\mathrm{mm}$ \\
$10 \mathrm{mM} \mathrm{W}-7$ & $18.6 \pm 1.0$ \\
$10^{-10}$ angiotensin II & $30.7 \pm 1.0^{*}$ \\
$10 \mathrm{mM} \mathrm{W}-7+10^{-10}$ angiotensin II & $19.9 \pm 0.8$
\end{tabular}

$n=5$ in each group. ${ }^{*} P<0.01$ vs other groups. 


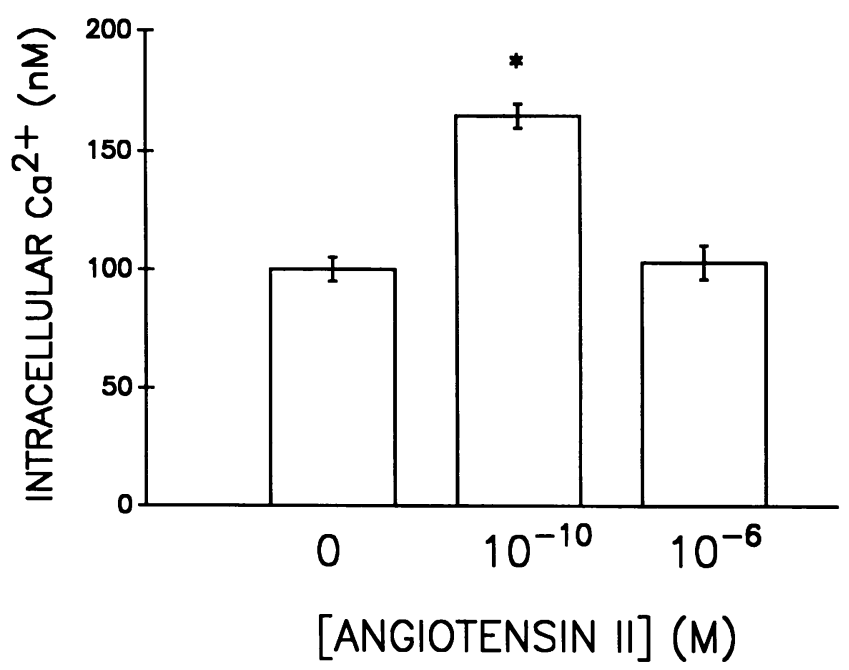

Figure 6. Angiotensin II increases $\left[\mathrm{Ca}^{2+}\right]_{\mathrm{i}}$ in proximal tubule cells at $10^{-10} \mathrm{M}$ but not at $10^{-6} \mathrm{M} .{ }^{*} P<0.01$ vs. $0 \mathrm{M}$ angiotensin II.

the bath and perfusion solutions by the addition of $1 \mathrm{mM}$ EGTA to $0 \mathrm{mM}$ calcium solutions. Removal of extracellular calcium blocked the stimulatory effect of angiotensin II on $\mathrm{tNH}_{3}$ production such that tubules incubated with angiotensin II produced $\mathrm{tNH}_{3}$ at a rate of $13.0 \pm 1.3 \mathrm{pmol} / \mathrm{min}$ per $\mathrm{mm}$, whereas those incubated with calcium removal only produced $\mathrm{tNH}_{3}$ at a rate of $15.4 \pm 0.8$ ( $n=4$ in each group). Similarly, removal of extracellular calcium blocked the sustained rise in $\left[\mathrm{Ca}^{2+}\right]_{\mathrm{i}}$ observed with exposure to $10^{-10} \mathrm{M}$ angiotensin II. The $\left[\mathrm{Ca}^{2+}\right]_{\mathrm{i}}$ of four proximal tubule segments was examined in the absence of extracellular calcium and with $10^{-10} \mathrm{M}$ angiotensin II in the absence of extracellular calcium. The baseline $\left[\mathrm{Ca}^{2+}\right]_{i}$ of proximal tubule segments in the absence of extracellular calcium was $92 \pm 4 \mathrm{nM}$ and remained unchanged after the addition of angiotensin II $(93 \pm 2 \mathrm{nM})$. Thus, the effects of $10^{-10} \mathrm{M}$ angiotensin $\mathrm{II}$ on $\mathrm{tNH}_{3}$ production and $\left[\mathrm{Ca}^{2+}\right]_{\mathrm{i}}$ were blocked by the removal of extracellular calcium.

\section{Discussion}

Angiotensin II is a potent regulator of transport by the proximal tubule $(1,2,4,21)$. The results of the present study demonstrate important effects of angiotensin II on $\mathrm{tNH}_{3}$ production and secretion by mouse proximal tubules. Angiotensin II stimulates $\mathrm{tNH}_{3}$ production at concentrations ranging from $10^{-11}$ to $10^{-9} \mathrm{M}$ and inhibits $\mathrm{tNH}_{3}$ production rates at concentrations $>10^{-8} \mathrm{M}$. In addition, the effect of angiotensin II at a concentration of $10^{-10} \mathrm{M}$ was completely inhibited by the angiotensin II antagonist saralasin, suggesting a receptor-mediated event.

These data differ in certain ways from the data of Chobanian and Julin (10). First, the stimulatory effect of angiotensin II on $\mathrm{tNH}_{3}$ production was observed at much higher concentrations of angiotensin II in the dog proximal tubule than in the mouse proximal tubule $\left(10^{-11} \mathrm{M}\right.$ in the mouse vs. $10^{-8} \mathrm{M}$ in the dog). Second, an inhibitory effect of angiotensin II was observed at high concentrations in mouse proximal tubules but not in dog tubules. The reason for the differences in these observations may be related to differences in the species used or to differences in the preparations studied (isolated perfused tubules vs. tubule fragment preparations).
A concentration-dependent effect of angiotensin II on $\mathrm{tNH}_{3}$ production follows a pattern similar to one observed by others $(1,2)$ for its effect on net fluid reabsorption by the proximal tubule. Net fluid reabsorption in rabbit proximal convoluted tubules was increased in the presence of $10^{-11} \mathrm{M}$ angiotensin II but was suppressed by $10^{-6} \mathrm{M}$ angiotensin II (2). The explanation for the biphasic nature of the effects of angiotensin II on net fluid reabsorption and on $\mathrm{tNH}_{3}$ production is not clear but may be related to differences in secondary messenger responses induced by different concentrations of angiotensin II.

The role of $\left[\mathrm{Ca}^{2+}\right]_{i}$ as a mediator for the stimulatory effect of angiotensin II on $\mathrm{tNH}_{3}$ production was suggested by the effect of W-7, an inhibitor of calcium-calmodulin-dependent kinase, to inhibit the action of $10^{-10} \mathrm{M}$ angiotensin $\mathrm{II}$ on $\mathrm{tNH}_{3}$ production. The present results are consistent with the results of Chobanian and Julin (10), who demonstrated that the stimulatory effect of angiotensin II on $\mathrm{tNH}_{3}$ production by dog proximal tubules was blocked by W-7. In the present studies, direct measurements of $\left[\mathrm{Ca}^{2+}\right]_{\mathrm{i}}$ suggest a correlation between the abilities of angiotensin II to induce a rise in $\left[\mathrm{Ca}^{2+}\right]_{i}$ and to stimulate $\mathrm{tNH}_{3}$ production. Concentrations of angiotensin II that do not stimulate $\mathrm{tNH}_{3}$ production do not cause a rise in $\left[\mathrm{Ca}^{2+}\right]_{i}$. Thus, a rise in $\left[\mathrm{Ca}^{2+}\right]_{\mathrm{i}}$ induced by lower concentrations of angiotensin II is associated with an increase in the rate of $\mathrm{tNH}_{3}$ production, while the mediator for the inhibitory effect of higher concentrations of angiotensin II is unclear and requires additional study.

These data contrast with studies demonstrating that angiotensin II at $10^{-5} \mathrm{M}$ induced a rise in $\left[\mathrm{Ca}^{2+}\right]_{i}$ in cultured rabbit proximal tubular cells (22) and in a rat proximal tubule preparation (23). These data also are inconsistent with recent studies by Chatsudthipong and Chan (24), who suggested that the inhibitory effect of angiotensin II on fluid and bicarbonate reabsorption was mediated by a rise in $\left[\mathrm{Ca}^{2+}\right]_{i}$. An explanation for the differences in results may be related to the differences in the models used. In the present study, the same isolated perfused tubule model was used to study the effects of angiotensin II on $\mathrm{tNH}_{3}$ production and on $\left[\mathrm{Ca}^{2+}\right]_{\mathrm{i}}$. In contrast, Chatsudthipong and Chan used the in vivo perfused rat proximal tubule to study the effects of angiotensin II on tubular transport and a different model, namely, a collagenase-treated proximal tubule preparation, to study the effect of angiotensin II on $\left[\mathrm{Ca}^{2+}\right]_{\mathrm{i}}$. It is possible that during the isolation procedure, the tubules lost some of their sensitivity to angiotensin II so that higher concentrations of angiotensin II were required to observe a rise in $\left[\mathrm{Ca}^{2+}\right]_{\mathrm{i}}$. Indeed, studies by Mujais (25) on collagenase-treated isolated rat proximal tubule segments demonstrated maximal specific binding at $10 \mathrm{nM}$ angiotensin II, a concentration 100 times higher than that required to achieve maximal stimulation of $\mathrm{tNH}_{3}$ production in the present study.

Changes in $\mathrm{pH}_{\mathrm{i}}$ could also serve as a primary stimulus for $\mathrm{tNH}_{3}$ production. Yet, angiotensin II at concentrations that stimulated $\left(10^{-10} \mathrm{M}\right)$ or inhibited $\left(10^{-6} \mathrm{M}\right) \mathrm{tNH}_{3}$ production rates did not significantly affect $\mathrm{pH}_{\mathrm{i}}$. Thus, the effect of angiotensin to stimulate $\mathrm{tNH}_{3}$ production was not mediated by measurable changes in $\mathrm{pH}_{\mathrm{i}}$.

Because the $\mathrm{pH}_{\mathrm{i}}$ remained constant during stimulation of luminal acidification (cellular acid exit), an increased rate of base exit must have accompanied the increased rate of acid exit. These data are consistent with the results of Geibel and colleagues (26), who demonstrated that angiotensin II stimulated both luminal $\mathrm{Na}^{+}-\mathrm{H}^{+}$exchange and basolateral $\mathrm{Na}^{+}$/ 
$\mathrm{HCO}_{3}^{-}$cotransport in the isolated perfused rabbit superficial $\mathrm{S}_{1}$ segment.

In contrast to the stimulatory effect of $10^{-10} \mathrm{M}$ angiotensin II on $\mathrm{tNH}_{3}$ production, $10^{-10} \mathrm{M}$ angiotensin II inhibited net luminal secretion of $\mathrm{tNH}_{3}$ so that the percentage of the $\mathrm{tNH}_{3}$ produced that was secreted was much lower in the presence of angiotensin II than in its absence. The inhibitory effect of angiotensin II on net $\mathrm{tNH}_{3}$ secretion occurred in the presence of enhanced luminal fluid acidification and in the absence of measurable changes in rates of $\mathrm{tNH}_{3}$ loss from the luminal fluid. These studies suggested that inhibition of net $\mathrm{tNH}_{3}$ secretion by angiotensin II resulted from diminished tubular cell secretion into the lumen rather than diminished production or enhanced luminal exit of $\mathrm{tNH}_{3}$.

The apparent dissociation between net $\mathrm{tNH}_{3}$ secretion and $\mathrm{Na}^{+}-\mathrm{H}^{+}$exchanger activity was surprising in view of both our previous study (14), demonstrating a marked dependence of net $\mathrm{tNH}_{3}$ secretion on $\mathrm{Na}^{+}-\mathrm{H}^{+}$exchange, and our present results, demonstrating stimulation of luminal fluid amiloridesensitive acidification. The results of the present studies suggested that angiotensin II did not alter net luminal $\mathrm{tNH}_{3}$ secretion by altering $\mathrm{tNH}_{3}$ efflux rates. One possible explanation for the apparent dissociation between angiotensin II-stimulated $\mathrm{Na}^{+}-\mathrm{H}^{+}$exchange activity and net $\mathrm{tNH}_{3}$ secretion could be that the affinity of the $\mathrm{Na}^{+}-\mathrm{H}^{+}$exchanger for $\mathrm{H}^{+}$compared with $\mathrm{NH}_{4}^{+}$was enhanced, so that $\mathrm{H}^{+}$secretion was enhanced, whereas $\mathrm{NH}_{4}^{+}$secretion was diminished.

The blocking effect of W-7 on the stimulatory effect of angiotensin II on luminal acidification suggested a role of the calcium-calmodulin pathway. The latter result contrasted with results of Weinman and co-workers (27), who demonstrated that calcium-calmodulin protein kinase II inhibited the activity of the reconstituted renal brush border $\mathrm{Na}^{+}-\mathrm{H}^{+}$exchanger. The reasons for the differences observed are unclear but may be related to differences in preparations (intact tubule vs. reconstituted $\mathrm{Na}^{+}-\mathrm{H}^{+}$exchanger).

The overall effect of angiotensin II on $\mathrm{tNH}_{3}$ delivery out of the proximal tubule depends on the net result of the contrasting effects of angiotensin II on $\mathrm{tNH}_{3}$ production and net secretion rates. At lower concentrations, angiotensin II stimulates $\mathrm{tNH}_{3}$ production and inhibits net luminal secretion by mouse proximal tubules such that the overall net effect is a reduction in net $\mathrm{tNH}_{3}$ secretion by the isolated perfused mouse proximal tubule. The countervailing effects of angiotensin II on production and transport of $\mathrm{tNH}_{3}$ may be important in limiting the effect of angiotensin II on overall acid-base balance. We have observed similar counteracting effects of luminal and bath potassium concentrations on $\mathrm{tNH}_{3}$ production and secretion in mouse proximal tubules (13). The opposing effects of angioten$\sin \mathrm{II}$ on $\mathrm{tNH}_{3}$ production and secretion rates represent another example of the dissociation between $\mathrm{tNH}_{3}$ production and transport in the proximal tubule.

The mechanism by which angiotensin II reduces net luminal secretion of $\mathrm{tNH}_{3}$ is unclear. The inhibitory effect of angiotensin II on net secretion could result from the inhibition of the luminal secretory step, from the stimulation of the basolateral exit pathway, or from the stimulation of the reabsorption of $\mathrm{tNH}_{3}$ from the lumen. The present data, which demonstrate that the luminal exit rate of $\mathrm{tNH}_{3}$ is not affected by angiotensin II, suggest that changes in reabsorption of $\mathrm{tNH}_{3}$ do not occur with angiotensin II. Whether angiotensin II, which stimu- lates the luminal $\mathrm{Na}^{+}-\mathrm{H}^{+}$exchanger (20) and basolateral $\mathrm{Na}^{+}$$\mathrm{K}^{+}$ATPase (28), also alters the transport characteristics of these transporters for $\mathrm{NH}_{4}^{+}(14,29-31)$ is speculative and requires further study.

In conclusion, angiotensin II has a concentration-dependent effect on $\mathrm{tNH}_{3}$ production; production is stimulated in the lower concentration ranges but inhibited at high concentrations. The stimulatory effect of angiotensin II is paralleled by angiotensin II-induced increases in intracellular calcium and is inhibited by the calmodulin pathway inhibitor, W-7. At a concentration that stimulates $\mathrm{tNH}_{3}$ production, angiotensin II inhibits net luminal $\mathrm{tNH}_{3}$ secretion by a mechanism not related to changes in transepithelial permeability to $\mathrm{tNH}_{3}$ and does not parallel changes in $\mathrm{Na}^{+}-\mathrm{H}^{+}$exchange.

\section{Acknowledgments}

This research was supported by the Department of Veterans Affairs and by a grant from the National Institute of Diabetes and Digestive and Kidney Diseases (DK-38463). G. T. Nagami is a Clinical Investigator of the Department of Veterans Affairs.

\section{References}

1. Harris, P. J., and J. A. Young. 1977. Dose-dependent stimulation and inhibition of proximal tubular reabsorption by angiotensin II in the rat kidney. Pfluegers Arch. 367:295-297.

2. Schuster, V. L., J. P. Kokko, and H. R. Jacobson. 1984. Angiotensin II directly stimulates sodium transport in rabbit proximal convoluted tubules. $J$. Clin. Invest. 73:507-515.

3. Harris, P. J., and L. G. Navar. 1985. Tubular transport responses to angiotensin. Am. J. Physiol. 248:F621-F630.

4. Liu, F.-Y., and M. G. Cogan. 1987. Angiotensin II. A potent regulator of acidification in the rat early proximal convoluted tubule. J. Clin. Invest. 80:272275.

5. Glabman, S., R. M. Klose, and G. Giebisch. 1963. Micropuncture study of ammonia excretion in the rat. Am. J. Physiol. 205:127-132.

6. Hayes, C. P., Jr., J. S. Mayson, E. E. Owens, and R. R. Robinson. 1964. A micropuncture evaluation of renal ammonia excretion in the rat. Am. J. Physiol. 207:77-83.

7. Sajo, I. M., M. B. Goldstein, H. Sonnenberg, B. J. Stinebaugh, D. R. Wilson, and M. L. Halperin. 1981. Sites of ammonia addition to tubular fluid in rats with chronic metabolic acidosis. Kidney Int. 20:353-358.

8. Buerkert, J., D. Martin, and D. Trigg. 1982. Ammonia handling by superfcial and juxtamedullary nephrons in the rat. J. Clin. Invest. 70:1-12.

9. Good, D. W., and M. B. Burg. 1984. Ammonia production by individual segments of the rat nephron. J. Clin. Invest. 73:602-610.

10. Chobanian, M. C., and C. M. Julin. 1991. Angiotensin II stimulates ammoniagenesis in canine renal proximal tubule cells. Am. J. Physiol. 260:F19-F26.

11. Nagami, G. T., and K. Kurokawa. 1985. Regulation of ammonia production by mouse proximal tubules perfused in vitro. Effect of luminal perfusion. $J$. Clin. Invest. 75:844-849.

12. Nagami, G. T., C. M. Sonu, and K. Kurokawa. 1986. Ammonia production by isolated mouse proximal tubules perfused in vitro. Effect of metabolic acidosis. J. Clin. Invest. 78:124-129.

13. Nagami, G. T. 1990. Effect of bath and luminal potassium concentration on ammonia production and secretion by mouse proximal tubules perfused in vitro. J. Clin. Invest. 86:32-39.

14. Nagami, G. T. 1988. Luminal secretion of ammonia in the mouse proximal tubule perfused in vitro. J. Clin. Invest. 81:159-164.

15. Brolin, S. E., A. Agren, J. P. Wersall, and S. Hjerren. 1978. Simplified bioluminescence analysis by continuous enzymatic reduction of $\mathrm{NADP}^{+}$using bacterial luciferase. Proceedings of the International Symposium on Analytical Applications of Bioluminescence and Chemiluminescence. E. Schram, and P. Stanley, editors. State Printing and Publishing, Westlake Village, California. 109121.

16. Thomas, J. A., R. N. Buchsbaum, A. Zimniak, and E. Racker. 1979. Intracellular pH measurements in Ehrlich ascites tumor cells utilizing spectroscopic probes generated in situ. Biochemistry. 18:2210-2218. 
17. Preisig, P. A., and R. J. Alpern. 1990. Pathways for apical and basolateral membrane $\mathrm{NH}_{3}$ and $\mathrm{NH}_{4}^{+}$movement in rat proximal tubule. Am. J. Physiol. 259:F587-F593.

18. Grynkiewicz, G., M. Ponie, and R. Y. Tsien. 1985. A new generation of $\mathrm{Ca}^{2+}$ indicators with greatly improved fluorescence properties. J. Biol. Chem. 260:3440-3448. York.

19. Scheffe, H. 1959. The Analysis of Variance. John Wiley \& Sons, New

20. Saccomani, G., K. D. Mitchell, and L. G. Navar. 1990. Angiotensin II stimulation of $\mathrm{Na}^{+}-\mathrm{H}^{+}$exchange in proximal tubules. Am. J. Physiol. 258:F1188F1195.

21. Liu, F.-Y., and M. G. Cogan. 1988. Angiotensin II stimulation of hydrogen ion secretion in the rat early proximal tubule. J. Clin. Invest. 82:601-607.

22. Welsh, C., G. Dubyak, and J. G. Douglas. 1988. Relationship between phospholipase $\mathrm{C}$ activation and prostaglandin E2 and cyclic adenosine monophosphate production in rabbit tubular epithelial cells. J. Clin. Invest. 81:710719.

23. Filburn, C. R., and S. Harrison. 1990. Parathyroid hormone regulation of cytosolic $\mathrm{Ca}^{2+}$ in rat proximal tubules. Am. J. Physiol. 258:F545-F552.
24. Chatsudthipong, V., and Y. L. Chan. 1991. Inhibitory effect of angiotensin II on renal tubular transport. Am. J. Physiol. 260:F340-F346.

25. Mujais, S. 1986. Angiotensin II binding sites in individual segments of the rat nephron. J. Clin. Invest. 77:315-318.

26. Geibel, J., G. Giebisch, and W. F. Boron. 1990. Angiotensin II stimulates both $\mathrm{Na}-\mathrm{H}$ exchange and $\mathrm{Na} / \mathrm{HCO}_{3}$ cotransport in rabbit proximal $\mathrm{S} 1$ tubules. Kidney Int. 37:537. (Abstr.)

27. Weinman, E. J., W. P. Dubinsky, K. Fisher, D. Steplock, Q. Dinh, L. Chang, and S. Shenolikar. 1988. Regulation of reconstituted renal $\mathrm{Na}+/ \mathrm{H}+\mathrm{ex}-$ changer by calcium-dependent protein kinases. J. Membr. Biol. 103:237-244.

28. Brown, G., and J. Douglas. 1989. Effect of angiotensin II infusion in rats on Na,K-ATPase activity in renal cortical microsomal preparations. Arch. Biochem. Biophys. 275:236-243.

29. Kinsella, J. L., and P. S. Aronson. 1981. Interaction of $\mathrm{NH}_{4}^{+}$and $\mathrm{Li}^{+}$with the renal microvillus membrane $\mathrm{Na}^{+}-\mathrm{H}^{+}$exchanger. Am. J. Physiol. 241:C220C226.

30. Garvin, J. L., M. B. Burg, and M. A. Knepper. 1985. Ammonium replaces potassium in supporting sodium transport by the $\mathrm{Na}^{+}-\mathrm{K}^{+}$ATPase of renal proximal straight tubules. Am. J. Physiol. 249:F785-F788.

31. Kurtz, I., and R. S. Balaban. 1986. Ammonium as a substrate for $\mathrm{Na}^{+}-\mathrm{K}^{+}$-ATPase in rabbit proximal tubules. Am. J. Physiol. 250:F497-F502. 